\title{
Epidemiology of carbapenem resistance among multi-drug resistant Enterobacteriaea
}

\author{
V Katawera ${ }^{1,2^{*}}$, L Ampaire ${ }^{3}$ \\ From 3rd International Conference on Prevention and Infection Control (ICPIC 2015) \\ Geneva, Switzerland. 16-19 June 2015
}

\section{Introduction}

Multi-drug resistant (MDR) Enterobacteriaceae are on the increase worldwide and their spread has become a global challenge. Escalating the challenge is the possibility that many of these are Carbapenemase-producing Enterobacteriaceae (CPE). This further complicates patient management. The magnitude of MDR-CPE in many developed settings has been reported, however, there is paucity of data from resource limited settings.

\section{Objectives}

We evaluated the epidemiology of MDR-CPE of clinical origin in South Western Uganda.

\section{Methods}

From September 2013 to June 2014, all Enterobacteriaceae isolated from diverse specimens obtained from patients attending Mbarara Regional Referral Hospital, South-western Uganda, were screened for MDR in a laboratory-based cross sectional study. Isolates found to be MDR were screened for carbapenem susceptibility/ resistance phenotypically by Kirby Bauer disc diffusion method following EUCAST guidelines and genetically using the multiplex real-time Polymerase Chain Reaction (RT-PCR).

\section{Results}

Of the 658 strains isolated, $183(27.8 \%)$ were MDR and $68(37.15 \%)$ of those MDR exhibited at least one form of carbapenem resistance with 23 (12.57\%) and 56 (30.60\%) isolates expressing phenotypic and genetic resistance, respectively. Eleven MDR-CPE (6.01\%) isolates exhibited both phenotypic and genotypic resistance to carbapenems. Only blaVIM and blaOXA-48 genes were detected among the genetically resistant isolates.

${ }^{1}$ Microbiology, Mbarara University, Mbarara, Uganda

Full list of author information is available at the end of the article

\section{Conclusion}

The high prevalence of MDR-CPE calls for aggressive infection control and prevention strategies, including reinforcement of hand hygiene, using contact precautions and early detection of CPE through use of targeted surveillance and molecular techniques in resource limited settings.

\section{Disclosure of interest}

None declared.

\section{Authors' details}

'Microbiology, Mbarara University, Mbarara, Uganda. 'Laboratory, Epicentre Mbarara Research Centre, Mbarara, Uganda. ${ }^{3}$ Medical Laboratory Sciences, Mbarara University, Mbarara, Uganda.

Published: 16 June 2015

doi:10.1186/2047-2994-4-S1-P133

Cite this article as: Katawera and Ampaire: Epidemiology of carbapenem resistance among multi-drug resistant Enterobacteriaea. Antimicrobial Resistance and Infection Control 2015 4(Suppl 1):P133.

Submit your next manuscript to BioMed Central and take full advantage of:

- Convenient online submission

- Thorough peer review

- No space constraints or color figure charges

- Immediate publication on acceptance

- Inclusion in PubMed, CAS, Scopus and Google Scholar

- Research which is freely available for redistribution 